\title{
Stem cell therapy for the spinal cord
}

\author{
Eleanor M Donnelly ${ }^{\dagger}$, Jason Lamanna ${ }^{\dagger}$ and Nicholas M Boulis*
}

\begin{abstract}
Injury and disease of the spinal cord are generally met with a poor prognosis. This poor prognosis is due not only to the characteristics of the diseases but also to our poor ability to deliver therapeutics to the spinal cord. The spinal cord is extremely sensitive to direct manipulation, and delivery of therapeutics has proven a challenge for both scientists and physicians. Recent advances in stem cell technologies have opened up a new avenue for the treatment of spinal cord disease and injury. Stem cells have proven beneficial in rodent models of spinal cord disease and injury. In these animal models, stem cells have been shown to produce their effect by the dual action of cell replacement and the trophic support of the factors secreted by these cells. In this review we look at the main clinical trials involving stem cell transplant into the spinal cord, focusing on motor neuron diseases and spinal cord injury. We will also discuss the major hurdles in optimizing stem cell delivery methods into the spinal cord. We shall examine current techniques such as functional magnetic resonance imaging guidance and cell labeling and will look at the current research striving to improve these techniques. With all caveats and future research taken into account, this is a very exciting time for stem cell transplant into the spinal cord. We are only beginning to realize the huge potential of stem cells in a central nervous system setting to provide cell replacement and trophic support. Many more trials will need to be undertaken before we can fully exploit the attributes of stem cells.
\end{abstract}

\section{Introduction}

Stem cell is a term used to describe a specific type of cell with two major characteristics: the capability to differentiate into multiple cell types and the ability to maintain a self-renewing population. There are numerous classes of stem cells, varying in their source and differentiation capabilities. Embryonic stem cells are termed pluripotent owing to their ability to differentiate into cells of all three germ layers $[1,2]$. Other stem cells, such as neuronal progenitor and adult stem cells, have more limited differentiation capabilities and are termed multipotent [3-6]. Multipotent stem cells are innately limited to differentiate only into cells from the lineages from which they were derived. Table 1 presents a list of the most relevant stem cells and their sources.

Injury and diseases of the spinal cord have classically had a bleak prognosis. This prognosis is not solely due to the nature of the disease, which affects the spinal cord, but to the difficulty faced in developing and delivering treatments to the spinal cord, which is extremely sensitive to direct manipulation. In this review we will look at how stem cell-derived therapies are evolving into exciting therapeutics for spinal cord medicine and changing the way we think about delivering treatments to the spinal cord. As well as discussing some of the most significant current clinical trials, we will examine the route involved in realizing the bench-to-bedside translation of these therapies.

The varying array of diseases that affect the spinal cord (Table 2) calls for a versatile and dynamic therapeutic approach. When developing any given therapeutic one must look closely at both the disease and the target tissue or tissues, carefully considering the limitations and specific barriers that must be overcome. Each disease has specific requirements and obstacles, and the treatment should be tailored to the specific disease.

Stem cells, or stem cell-derived cells, can most simply be used to replace lost cells such as oligodendrocytes, neurons, motor neurons and astrocytes. These cells may also provide an additional therapeutic effect by secreting factors that are neuroprotective or that promote neuroregeneration, such as cytokines and growth factors [16]. The modification of stem cells via gene therapy to produce or reduce specific factors is an additional level of specificity, which allows the therapeutic to target specific aspects of the disease under investigation [17].

Before discussing the use of stem cells and stem cellderived cells, it is important to pause for a moment to consider the ethical issues associated with their use. 
Table 1. Sources, advantages and disadvantages of the main sources of stem cells

\begin{tabular}{|c|c|c|c|c|}
\hline & $\begin{array}{l}\text { Differentiation } \\
\text { capability }\end{array}$ & Source & Advantages & Disadvantages \\
\hline Embryonic stem cells $[1,2]$ & Pluripotent & Blastocyst & Pluripotent & $\begin{array}{l}\text { Ethical concerns, biomanufacturing } \\
\text { issues }\end{array}$ \\
\hline Neuronal progenitors $[3,4]$ & Multipotent & Fetal/embryonic tissue & & $\begin{array}{l}\text { Ethical concerns, biomanufacturing } \\
\text { issues }\end{array}$ \\
\hline $\begin{array}{l}\text { Adult central nervous } \\
\text { system stem cells [7] }\end{array}$ & Multipotent & $\begin{array}{l}\text { Adult central nervous } \\
\text { system }\end{array}$ & $\begin{array}{l}\text { Autologous, no ethical } \\
\text { concerns }\end{array}$ & $\begin{array}{l}\text { Limited differentiation potential, } \\
\text { biomanufacturing issues, require } \\
\text { surgical harvest }\end{array}$ \\
\hline $\begin{array}{l}\text { Adult mesenchymal } \\
\text { stem cells [5] }\end{array}$ & Multipotent & Adult bone marrow & $\begin{array}{l}\text { Autologous, easily obtained, } \\
\text { no ethical concerns }\end{array}$ & $\begin{array}{l}\text { Limited differentiation potential, } \\
\text { biomanufacturing issues. }\end{array}$ \\
\hline Umbilical cord cells [8] & Multipotent & Umbilical cord & $\begin{array}{l}\text { Autologous, no ethical } \\
\text { concerns }\end{array}$ & $\begin{array}{l}\text { Limited differentiation potential, } \\
\text { biomanufacturing issues }\end{array}$ \\
\hline $\begin{array}{l}\text { Induced pluripotent stem } \\
\text { cells [6] }\end{array}$ & Multipotent/pluripotent & Skin & $\begin{array}{l}\text { Autologous, no ethical } \\
\text { concerns, potential for } \\
\text { pluripotency }\end{array}$ & $\begin{array}{l}\text { Require addition of viral vectors } \\
\text { for induced pluripotency, } \\
\text { biomanufacturing issues }\end{array}$ \\
\hline
\end{tabular}

There is an ongoing debate regarding the ethics of using cells that are derived from human fetal and embryonic origins. The destruction of these fetuses and embryos for research is of great ethical concern and debate. We shall not enter into this debate in the present review; interested readers may wish to refer to the National Institutes of Health webpage on this issue [18].

\section{Delivery methods}

Several promising methods are employed for transplanting stem cells into the spinal cord. Intravascular infusion, intrathecal infusion and direct intraparenchymal injection have all been utilized in human clinical trials (see Table 3). While these methods have been used in the clinic, the most effective method has yet to be determined. This uncertainty remains a critical debate with major implications for the future success of stem cell therapy in the spinal cord.

Systemic delivery methods, such as intravascular and intrathecal infusion, rely on the stem cells' ability to migrate to local areas of pathology. While this migration capability has been well described in small animal models, convincing evidence in large animal models is still lacking [23-25]. Regardless, systemic approaches have been used in many stem cell clinical trials in the spinal cord but with limited success. In a trial for chronic spinal cord injury (SCI), magnetically labeled autologous bone marrow $\mathrm{CD}_{4} 4^{+}$cells delivered by intrathecal infusion and visualized by magnetic resonance imaging (MRI) were shown to migrate to the injured site [26]. Migration has been noted in other trials in the spinal cord using systemic approaches [27].

Direct intraparenchymal injection delivers stem cells directly to the area of pathology and does not require systemic migration of cells. Paul and colleagues compared different methods of mesenchymal stem cell
(MSC) transplantation in a rat model of SCI [28]. Twenty-one days after a single dose, $6.1 \%$ of cells engrafted with direct intraparenchymal injection compared with $3.4 \%$ and $1.6 \%$ with intravenous infusion and intrathecal infusion, respectively. This study demonstrated that direct injection is the preferred method of delivery even with only $6.1 \%$ of cells detectable 21 days post transplantation in a rat spinal cord. Furthermore, direct spinal cord injection allows for accurate and reliable delivery that can easily be scaled up to humans, but carries the additional risk of manipulation of spinal cord pathology.

Various approaches for direct intraparenchymal injection have been developed. All direct injection approaches require a multilevel laminectomy and opening of the dura mater to expose the spinal cord. In small animal studies, intraparenchymal injections are frequently and successfully performed without stabilization using a free-hand method $[29,30]$. This presents several problems for translation to humans. First, it does not allow reliable targeting in the spinal cord. Second, the unsteady needle can move and shear white matter tracts. Finally, the uncontrolled rate of injection promotes reflux of the therapeutic agent up the cannula track and increases the risk for spinal cord mass effect by elevated intraparenchymal pressure. In spite of these inherent risks, free-hand intraparenchymal injections of stem cells have been performed in several clinical trials for SCI and amyotrophic lateral sclerosis (ALS) with limited success [31-34]. Moreover, because no device is used in this approach, there are no additional regulatory hurdles associated with using a novel device.

Injection systems mounted on the operating room table provide several advantages over the free-hand approach $[35,36]$. When used with microinjection pumps and micromanipulators, table-mounted systems allowed better control over the injection rate and pressure and more accurate landmark-based targeting. The table-mounted 
Table 2. Traumatic and motor neuron disease of the spinal cord, and potential for stem cell transplant

\begin{tabular}{|c|c|c|c|c|c|c|c|}
\hline $\begin{array}{l}\text { Disease } \\
\text { class }\end{array}$ & $\begin{array}{l}\text { Disease/ } \\
\text { disorder }\end{array}$ & $\begin{array}{l}\text { Symptoms/ } \\
\text { phenotype }\end{array}$ & Mechanism & $\begin{array}{l}\text { Present } \\
\text { treatments }\end{array}$ & $\begin{array}{l}\text { Demo- } \\
\text { graphics }\end{array}$ & $\begin{array}{l}\text { Possibility for stem } \\
\text { cell treatment }\end{array}$ & Stem cell clinical trials \\
\hline Traumatic & $\begin{array}{l}\text { Spinal cord } \\
\text { injury }\end{array}$ & $\begin{array}{l}\text { Varying in extent } \\
\text { and level of injury } \\
\text { (as classified by } \\
\text { ASIA scale), loss of } \\
\text { sensation to paralysis }\end{array}$ & $\begin{array}{l}\text { Traumatic injury, } \\
\text { cell loss, axonal } \\
\text { and myelin } \\
\text { degeneration, } \\
\text { cytotoxic } \\
\text { environment }\end{array}$ & $\begin{array}{l}\text { Decompression } \\
\text { and stabilization } \\
\text { surgeries, } \\
\text { rehabilitation }\end{array}$ & $\begin{array}{l}250,000 \\
\text { sufferers in } \\
\text { the USA }\end{array}$ & $\begin{array}{l}\text { Cell replacement, } \\
\text { trophic support } \\
\text { produced by } \\
\text { transplanted cells, } \\
\text { modified stem cells } \\
\text { to secrete specific } \\
\text { trophic factors, axonal } \\
\text { regeneration }\end{array}$ & $\begin{array}{l}\text { Geron Corp. } \\
\text { ID\# NCT01217008 [9], } \\
\text { Memorial Hermann } \\
\text { Healthcare System } \\
\text { ID\# NCT01328860 } \\
\text { [10], Stem Cells Inc. } \\
\text { ID\# NCT01321333 [11] }\end{array}$ \\
\hline \multirow[t]{2}{*}{ Motor neuron } & $\begin{array}{l}\text { Amyotrophic } \\
\text { lateral } \\
\text { sclerosis }\end{array}$ & $\begin{array}{l}\text { Neurodegeneration, } \\
\text { muscle wastage, } \\
\text { paralysis }\end{array}$ & $\begin{array}{l}\text { Upper and } \\
\text { lower motor } \\
\text { neuron loss, glia } \\
\text { dysfunction, } \\
\text { both familial and } \\
\text { sporadic }\end{array}$ & $\begin{array}{l}\text { One approved } \\
\text { drug, riluzole }\end{array}$ & $5: 100,000$ & $\begin{array}{l}\text { Trophic support to } \\
\text { promote survival } \\
\text { of motor neurons, } \\
\text { regeneration of axons }\end{array}$ & $\begin{array}{l}\text { Neuralstem Inc. } \\
\text { ID\# NCT01348451 } \\
\text { [12], BrainStorm Cell } \\
\text { Therapeutics, Ltd } \\
\text { ID\# NCT01051882 [13], } \\
\text { TCA Cellular Therapy } \\
\text { ID\# NCT01082653 [11,14] }\end{array}$ \\
\hline & $\begin{array}{l}\text { Spinal } \\
\text { muscular } \\
\text { atrophy }\end{array}$ & $\begin{array}{l}\text { Childhood disease, } \\
\text { neurodegeneration, } \\
\text { muscle wastage, } \\
\text { paralysis }\end{array}$ & $\begin{array}{l}\text { Inherited } \\
\text { autosomal } \\
\text { disease, lower } \\
\text { motor neuron } \\
\text { loss }\end{array}$ & $\begin{array}{l}\text { None as of } \\
\text { present }\end{array}$ & $1: 6,000$ & $\begin{array}{l}\text { Trophic support to } \\
\text { promote survival } \\
\text { of motor neurons, } \\
\text { regeneration of axons }\end{array}$ & $\begin{array}{l}\text { California Stem Cells } \\
\text { Inc. [15] }\end{array}$ \\
\hline Inflammatory & $\begin{array}{l}\text { Multiple } \\
\text { sclerosis }\end{array}$ & $\begin{array}{l}\text { Multisymptomatic } \\
\text { presentation, } \\
\text { including motor } \\
\text { dysfunction and vision } \\
\text { defects }\end{array}$ & $\begin{array}{l}\text { Degeneration } \\
\text { of myelin, due } \\
\text { to autoimmune } \\
\text { response }\end{array}$ & $\begin{array}{l}\text { Steroids and anti } \\
\text { inflammatory } \\
\text { drug to delay } \\
\text { progression }\end{array}$ & $\begin{array}{l}250,000 \text { in } \\
\text { the USA }\end{array}$ & $\begin{array}{l}\text { Replacement of } \\
\text { myelin producing } \\
\text { oligodendrocytes }\end{array}$ & $\begin{array}{l}\text { Northwestern University, } \\
\text { Hadassah Medical } \\
\text { Organization, Jerusalem }\end{array}$ \\
\hline
\end{tabular}

ASIA, American Spinal Injury Association.

system also provides a degree of stability to the injection cannula. However, this system does not account for movement of the patient or spinal cord with respect to the injection cannula. Ventilation-associated motion of the patient, cardiovascular pulsation of the spinal cord and movement of the patient or table-mounted injection system may lead to injury of an already weakened spinal cord.

To address the concerns of potential procedural morbidity and suboptimal accuracy, our group developed an injection system that mounts to the patient's spine for optimal stability [37-40]. The injection platform can be immobilized relative to the spine with percutaneous mounts attached to vertebral pedicles flanking the injection site. The spine mounts allow the injection system to move with the patient during ventilation and in the event of inadvertent patient movement. The stabilized platform also allows for accurate landmark-based targeting with the adjustable microinjector attached to the platform. The platform allows for rostrocaudal displacement and angular manipulations in the coronal, sagittal and axial planes of the microinjector to accommodate multilevel injections. This injection system utilizes an outer rigid cannula for accurate targeting and an inner flexible or floating cannula for cell delivery. The flexibility provided by the floating cannula compensates for the natural pulsation of the spinal cord with ventilation and heartbeat. These innovations reduced the procedural risks associated with direct intraparenchymal injection and improved targeting capability [40]. The safety and accurate targeting using this system has been extensively assessed by preclinical work [38,40,41]. Initial use of this delivery system in a clinical setting has shown encouraging results $[42,43]$. While these innovations allow for safer and more accurate delivery, many improvements must be made to further optimize the delivery of stem cells to the human spinal cord, such as incorporating image-guided techniques.

\section{Stem cells in clinical trials for treatment of the spinal cord and their journey from bench to bedside}

To facilitate the translation of stem cells from bench to bedside and to satisfy all regulatory bodies, extensive preclinical work in animal models must be undertaken and must provide sufficient evidence that the proposed treatment is both safe and effective. The translation process from basic research through investigational new drug to human clinical trials is long and complex. For an in-depth review on the regulatory progress of translation of stem cell treatments, please see the comprehensive review by Aboody and colleagues [44].

Before we look at the translations of stem cells to the clinic we must take note of the caveats that are linked to 
Table 3. Current clinical trials transplanting stem cells into the spinal cord

\begin{tabular}{|c|c|c|c|c|c|c|c|}
\hline Year & Location/sponsor & Cells & Indication & Delivery & Inclusion criteria & Status & References \\
\hline 2009 & $\begin{array}{l}\text { Palo Alto, CA; } \\
\text { Atlanta, GA; } \\
\text { Chicago, IL; } \\
\text { Philadelphia, PA, } \\
\text { USA (Geron Corp.) }\end{array}$ & $\begin{array}{l}\text { Allogenic human } \\
\text { ESC-derived } \\
\text { oligodendrocytes } \\
\text { (GRNOPC } 1^{*} \text { ) }\end{array}$ & $\mathrm{SCl}$ & $\begin{array}{l}\text { Direct single injection to the } \\
\text { spinal cord lesion using a table- } \\
\text { mounted syringe positioning } \\
\text { device ( } 2 \text { million cells) }\end{array}$ & $\begin{array}{l}\text { Adult subacute } \\
\text { complete thoracic } \\
\text { SCI (ASIA grade A) }\end{array}$ & $\begin{array}{l}\text { FDA phase } 1 . \\
\text { Terminated }\end{array}$ & $\begin{array}{c}\text { ID\# NCT01217008 } \\
{[9,11]}\end{array}$ \\
\hline 2010 & $\begin{array}{l}\text { Atlanta, GA, USA } \\
\text { (Neuralstem Inc.) }\end{array}$ & $\begin{array}{l}\text { Allogenic human } \\
\text { fetal spinal cord- } \\
\text { derived spinal } \\
\text { stem cells (NSI- } \\
\text { 566RSC) }\end{array}$ & ALS & $\begin{array}{l}\text { Direct multiple injections to the } \\
\text { ventral horn of the lumbar or } \\
\text { cervical enlargement using a } \\
\text { spine-mounted microinjection } \\
\text { platform ( } 0.5 \text { to } 1 \text { million cells) }\end{array}$ & $\begin{array}{l}\text { Adult probable } \\
\text { or definite ALS } \\
\text { defined according } \\
\text { to El Escorial } \\
\text { criteria }\end{array}$ & $\begin{array}{l}\text { FDA phase } 1 . \\
\text { Recruiting }\end{array}$ & $\begin{array}{c}\text { ID\# NCT01348451 } \\
{[11,12]}\end{array}$ \\
\hline 2011 & $\begin{array}{l}\text { Irvine, CA, USA } \\
\text { (California Stem } \\
\text { Cell, Inc.) }\end{array}$ & $\begin{array}{l}\text { Allogenic human } \\
\text { ESC-derived } \\
\text { motor neuron } \\
\text { progenitor cells } \\
\text { (MotorGraft }{ }^{\mathrm{TM}} \text { ) }\end{array}$ & SMA & $\begin{array}{l}\text { Direct multiple injections to } \\
\text { the ventral horn of the thoracic } \\
\text { spinal cord }\end{array}$ & $\begin{array}{l}\text { Infant (age } 2 \text { to } \\
6 \text { months) SMA } \\
\text { type } 1\end{array}$ & $\begin{array}{l}\text { FDA clinical hold. } \\
\text { Reviewing IND }\end{array}$ & [15] \\
\hline 2001 & Italy & $\begin{array}{l}\text { Autologous } \\
\text { human bone } \\
\text { marrow-derived } \\
\text { mesenchymal } \\
\text { stem cells }\end{array}$ & ALS & $\begin{array}{l}\text { Direct multiple injections to } \\
\text { the central gray matter of the } \\
\text { lumbar enlargement using a } \\
\text { table-mounted injector ( } 7 \text { to } \\
152 \text { million cells) }\end{array}$ & $\begin{array}{l}\text { Adult definite ALS } \\
\text { defined according } \\
\text { to El Escorial } \\
\text { criteria }\end{array}$ & $\begin{array}{l}\text { Phase } 1 . \\
\text { Completed }\end{array}$ & $\begin{array}{c}\text { Mazzini and } \\
\text { colleagues [19-21] }\end{array}$ \\
\hline 2011 & $\begin{array}{l}\text { Zurich, } \\
\text { Switzerland (Stem } \\
\text { Cells Inc.) }\end{array}$ & $\begin{array}{l}\text { Allogenic fetal } \\
\text { brain-derived } \\
\text { human central } \\
\text { nervous system } \\
\text { stem cells } \\
\text { (HuCNS-SC) }\end{array}$ & $\mathrm{SCl}$ & $\begin{array}{l}\text { Direct multiple injections to the } \\
\text { inferior and superior border of } \\
\text { spinal cord lesion ( } 20 \text { million } \\
\text { cells) }\end{array}$ & $\begin{array}{l}\text { Adult thoracic } \\
\text { chronic SCI (ASIA } \\
\text { grade } A, B, \text { or } C \text { ) }\end{array}$ & $\begin{array}{l}\text { Swiss medic } \\
\text { phase } 1 / 2 \text {. } \\
\text { Recruiting }\end{array}$ & $\begin{array}{c}\text { ID\# NCT01321333 } \\
{[11,22]}\end{array}$ \\
\hline 2011 & $\begin{array}{l}\text { Jerusalem, Israel } \\
\text { (BrainStorm Cell } \\
\text { Therapeutics, Ltd) }\end{array}$ & $\begin{array}{l}\text { Autologous } \\
\text { human } \\
\text { mesenchymal } \\
\text { bone marrow } \\
\text { stromal cells } \\
\text { secreting } \\
\text { neutrotrophic } \\
\text { factors }\end{array}$ & ALS & $\begin{array}{l}\text { Early stage: multiple } \\
\text { intramuscular injections to } \\
\text { triceps and biceps muscles ( } 24 \\
\text { million cells). Late stage: single } \\
\text { intrathecal injection ( } 60 \text { million } \\
\text { cells) }\end{array}$ & $\begin{array}{l}\text { ALS disease } \\
\text { duration < } 2 \text { years; } \\
\text { and ALS-FRS-R } \\
\text { scale }>30 \text { (early } \\
\text { stage) or ALS- } \\
\text { FRS-R scale } 15 \text { to } \\
30 \text { (late stage) }\end{array}$ & $\begin{array}{l}\text { Israel Ministry of } \\
\text { Health phase } 1 / 2 \text {. } \\
\text { Recruiting }\end{array}$ & $\begin{array}{c}\text { ID\# NCT01051882 } \\
{[11,13]}\end{array}$ \\
\hline 2011 & $\begin{array}{l}\text { Houston, TX, } \\
\text { USA (Memorial } \\
\text { Hermann } \\
\text { Healthcare } \\
\text { System) }\end{array}$ & $\begin{array}{l}\text { Autologous } \\
\text { human bone } \\
\text { marrow-derived } \\
\text { progenitor cells }\end{array}$ & $\mathrm{SCl}$ & Single intravenous infusion & $\begin{array}{l}\text { Children age } 1 \\
\text { to } 15 \text { years with } \\
\text { chronic SCl }\end{array}$ & $\begin{array}{l}\text { FDA phase } 1 . \\
\text { Recruiting }\end{array}$ & $\begin{array}{c}\text { ID\# NCT01328860 } \\
{[10,11]}\end{array}$ \\
\hline 2010 & $\begin{array}{l}\text { Covington, LA, } \\
\text { USA (TCA Cellular } \\
\text { Therapy, LLC) }\end{array}$ & $\begin{array}{l}\text { Autologous } \\
\text { human bone } \\
\text { marrow-derived } \\
\text { mesenchymal } \\
\text { stem cells }\end{array}$ & ALS & Single intrathecal infusion & $\begin{array}{l}\text { Moderate to } \\
\text { severe ALS with El } \\
\text { Escorial criteria }\end{array}$ & $\begin{array}{l}\text { FDA phase } 1 . \\
\text { Ongoing }\end{array}$ & $\begin{array}{c}\text { ID\# NCT01082653 } \\
{[11,14]}\end{array}$ \\
\hline 2010 & $\begin{array}{l}\text { Covington, LA, } \\
\text { USA (TCA Cellular } \\
\text { Therapy, LLC) }\end{array}$ & $\begin{array}{l}\text { Autologous } \\
\text { human bone } \\
\text { marrow-derived } \\
\text { mesenchymal } \\
\text { stem cells }\end{array}$ & $\mathrm{SCl}$ & Single intrathecal infusion & $\begin{array}{l}\text { Subacute } \\
\text { complete SCI } \\
\text { below C-5 (ASIA } \\
\text { grade A) }\end{array}$ & $\begin{array}{l}\text { FDA phase } 1 . \\
\text { Ongoing }\end{array}$ & $\begin{array}{c}\text { ID\# NCT01162915 } \\
{[11,14]}\end{array}$ \\
\hline 2010 & $\begin{array}{l}\text { Rochester, MN, } \\
\text { USA (Mayo Clinic) }\end{array}$ & $\begin{array}{l}\text { Autologous } \\
\text { human adipose } \\
\text { tissue-derived } \\
\text { mesenchymal } \\
\text { stem cells }\end{array}$ & ALS & $\begin{array}{l}\text { Single intrathecal infusion (1 } \\
\text { million cells) }\end{array}$ & $\begin{array}{l}\text { Adult with } \\
\text { chronic onset of a } \\
\text { progressive motor } \\
\text { weakness }\end{array}$ & $\begin{array}{l}\text { FDA phase } 1 . \\
\text { Ongoing }\end{array}$ & $\begin{array}{c}\text { ID\# NCT01142856 } \\
\text { [11] }\end{array}$ \\
\hline 2000 & $\begin{array}{l}\text { Israel and Belgium } \\
\text { (Proneuron } \\
\text { Biotech) }\end{array}$ & $\begin{array}{l}\text { Autologous } \\
\text { human } \\
\text { macrophages }\end{array}$ & $\mathrm{SCl}$ & $\begin{array}{l}\text { Direct multiple hand-held } \\
\text { injections at the caudal border } \\
\text { of the spinal cord lesion ( } 4 \\
\text { million cells) }\end{array}$ & $\begin{array}{l}\text { Adult acute } \\
\text { complete } \mathrm{SCl} \\
\text { between } \mathrm{C} 5 \text { and } \\
\text { T11 (ASIA grade A) }\end{array}$ & $\begin{array}{l}\text { Phase } 1 . \\
\text { Suspended }\end{array}$ & $\begin{array}{c}\text { ID\# NCT00073853 } \\
\text { [11] }\end{array}$ \\
\hline 2006 & $\begin{array}{l}\text { Jerusalem, } \\
\text { Israel (Hadassah } \\
\text { Medical } \\
\text { Organization) }\end{array}$ & $\begin{array}{l}\text { Autologous } \\
\text { human bone } \\
\text { marrow-derived } \\
\text { mesenchymal } \\
\text { stem cells }\end{array}$ & MS & $\begin{array}{l}\text { Intrathecal infusion of } 60 \text { million } \\
\text { cells and intravenous infusion of } \\
20 \text { million cells }\end{array}$ & Definite MS & $\begin{array}{l}\text { Israel Ministry of } \\
\text { Health phase } 1 / 2 \text {. } \\
\text { Status unknown }\end{array}$ & $\begin{array}{c}\text { ID\# NCT00781872 } \\
\text { [11] }\end{array}$ \\
\hline
\end{tabular}


stem cells, as with all developing therapeutics. Extensive preclinical work must establish that there is no risk of tumor formation, which is a major safety concern when dealing with stem cells. The immune response and rejection of nonautologous cells is also a considerable concern for stem cell researchers and clinicians. This rejection necessitates that many patients who received stem cell transplants are required to take immunosuppressive drugs, which in turn have their own adverse effects and complications. It is also important to note that the generation of clinical-grade stem cells is subjected to its own unique obstacles that have to be overcome, such as kartotype problems and removal of substances utilized during biomanufacturing.

Geron Corp. (Menlo Park, CA, USA) was the first company to bring human embryonic stem cell-derived cells through US Food and Drug Administration (FDA) approval for human phase 1 clinical trials. Owing to this important first, the Geron Corp. trial gained attention in both the scientific world but also in the general media. Geron Corp.'s combination of stem cell type and disease demonstrates the specific tailoring required for stem cell translation. They chose to look at stem cell transplantation for SCI. Following SCI, a glial scar and cyst are formed, many surviving axons are subjected to myelin loss, and cytotoxic and inhibitory factors are produced by the glial scar [45]. Human embryonic-derived oligodendrocyte precursor cells injected into the injured rodent spinal cord have been shown to migrate to the lesion site, to provide trophic support to surviving axons, and also to differentiate into mature oligodendrocytes that are capable of remyelination of the surviving axons. The combination of cell replacement and trophic support brought about significant locomotor improvement in the rodent model and long-term remyelination of the surviving and regenerated axons. Geron Corp. and their collaborators embarked on an extensive preclinical safety study in a rodent model of SCI. This study examined teratoma formation, toxicity, cyst formation, allodynia and allogenic immune response. Despite the absence of a large animal study, Geron Corp. was granted FDA approval for the delivery of human embryonic stem cellderived oligodendrocyte precursor cells into the lesion site of subacute thoracic SCI. It is important to note not only that the scientific precedence set by this trial but also the approval of the trial using embryonic stem cells went a long way in dealing with the ethical issues surrounding the use of these and other embryonic stem cells. Specific details of this trail can be found online [9].

Neuralstem Inc. (Atlanta, GA, USA) and their collaborators chose to pursue the ALS agenda as a disease state for which stem cells can offer a potentially powerful therapeutic. ALS is a complex disease involving motor neuron loss, muscle innervation loss and glia dysfunction.
Simple cell replacement is not sufficient to result in reinnervation of affected muscles. Transplanted cells must provide both cell replacement and trophic support $[46,47]$. The trophic support may be from the stem cells' own endogenous growth factor profile, or the cells may be modified to produce specific growth factors via ex vivo gene therapy [48-50]. Again this concept of both cell replacement and trophic support demonstrates that stem cells' positive attributes are not mutually exclusive in a therapeutic setting. Owing to the discovery of the SOD-1 mutation in familial ALS, a rodent model of ALS was developed - giving us a reliable model in which to observe the development of the disease and a platform from which to examine the potential of stem cell transplantation in this disease state [51-53]. In-depth research has been carried out to prove the efficacy of stem cell transplantation in the SOD-1 rodent models. Human spinal stem cells have been shown to reduce loss of motor neuron and prolong SOD-1 rat survival $[17,47,54]$. Following these promising results in rodent models, Neuralstem Inc. and their collaborators embarked on large-animal safety studies. Pigs were chosen as the best model due to the similarity to the human spinal cord. The pig experiments allowed the cord's tolerance to injection doses and number of injections to be determined. In combination with this critical safety study, rodent efficacy data and the development of a novel injection platform to reduce surgical complexity, Neuralstem Inc. and their collaborators were the first to receive approval for the first translational trial of stem cells for the treatment of ALS. This trial is presently in phase 1 to evaluate the safety and feasibility of direct injection of stem cells into the spinal cord. A positive outcome of this phase 1 safety trial will pave the way for the continued translation of stem cells $[42,43]$.

California Stem Cell, Inc. (Irvine, CA, USA ) and the University of California, Irvine worked together on developing embryonic stem cell-derived motor neuron progenitors as a potential therapeutic approach for spinal muscular atrophy. An autosomal recessive neuromuscular disease, spinal muscular atrophy is the leading genetic cause of mortality in children. Spinal muscular atrophy is characterized by muscle paralysis and atrophy, associated with loss of spinal cord motor neurons $[55,56]$. California Stem Cell, Inc.s motor neuron progenitors have been shown to improve neuronal survival in three separate models of spinal muscular atrophy [57] and also have shown functional recovery in models of SCI [58]. California Stem Cell, Inc. branded these cells Motorgraft and received investigational new drug status in 2010. Following review the FDA placed this potential trial on clinical hold. California Stem Cell, Inc. is currently working to address the FDA comments and recommendations necessary for approval. 
In Europe a team of Italian scientists and physicians have been progressing the adult stem cell agenda. MSCs have been showed to have anti-inflammatory effects, which have been observed to reduce the inflammatory and reactive state of microglia and astrocytes, promoting a protective microenvironment [59]. Human MSCs have been observed to improve motor function and reduce inflammation in a mouse model of ALS [60]. MSC harvested from ALS patients has been shown to present the same differentiation potential as those from normal donors and they have no other observable chromosomal or cellular abnormalities [61]. These findings suggest that the autologous cells can be used, eliminating the risk of host rejection and the need for immunosuppression. This work has proceeded to clinical trial. The first phase I safety data from this trial showed no adverse effect [19]. The long-term safety results of this trial ( $>8$ years) showed no adverse effects [20]. No beneficial effects were observed. A more comprehensive trial is called for to assess the potential of these adult stem cells.

\section{Optimizing delivery}

Future methods of transplanting stem cells into the spinal cord must aim to both improve targeting capabilities and reduce procedural morbidity. Advanced imaging and image-guided techniques offer a means to accomplish both of these aims. MRI can allow for direct targeting of spinal cord anatomy and pathology with its unparalleled spatial resolution in the central nervous system.

Current clinical trials directly injecting stem cells utilize MRI for preoperative planning and naked-eye visual observation of spinal cord surface anatomy for calculating the final injection site. Although the current method is accurate, direct visualization of the injection cannula within the spinal cord using MRI would offer greater targeting accuracy and confirm the location of the injected cells. MRI-guided approaches are well established in the brain for implantation of deep brain stimulation electrodes [62,63] and various other procedures. With the increasing availability of intraoperative MRI suites, the prospect of injecting stem cells directly into the spinal cord during surgery with the guidance of realtime MRI is becoming a reality. However, modifications must be made to the current generation of injection devices to make them MRI compatible.

Further improvements may create intraoperative MRI injection devices capable of direct delivery to the spinal cord parenchyma percutaneously, eliminating the need for open surgery. Before this is possible, extensive preclinical validation must be done in large animal models to assess targeting ability and morbidity associated with the new procedure. Directly injecting cells percutaneously creates many new concerns: cerebrospinal fluid leak associated with multiple punctures of the dura mater; uncontrolled hemorrhage from damaged spinal cord blood vessels; inaccurate targeting due to displacement of the spinal cord from cannula insertion; and a limited range of injection sites due to obstruction from the vertebral column.

\section{Cell tracking}

Another critical issue faced in most stem cell trials is the inability to monitor the cell grafts post transplantation. This inability has made it difficult to understand the fate of the graft in vivo, specifically in terms of cell graft location, survival and migration. Furthermore, even identifying the cell graft on postmortem tissue histology can prove challenging due to the low number of cells and limitations in histological techniques. These critical issues highlight the need for a cell label that allows for in vivo visualization and/or postmortem detection.

Cells may be visualized in vivo when labeled with a biomarker or contrast agent prior to transplantation. Many different approaches have been used to label stem cells, such as superparamagnetic iron oxide (SPIO) particles for MRI visualization, radionuclides for positron emission tomography and/or single-photon emission computed tomography visualization and reporter genes for a wide variety of imaging modalities. Methods for labeling stem cells have been well described and have been utilized in a wide variety of clinical trials [64,65].

The ability to track SPIO particle-labeled stem cells transplanted into the central nervous system has been validated in numerous small animal studies and demonstrated in several clinical trials [26,27,66-69]. These pioneering trials confirm both the ability to visualize labeled stem cells in vivo and the safety of these labeling approaches. Initially, these labeling methods proved most valuable in determining an initial graft location $[69,70]$. However, the follow-up imaging on these few patients was not long term and postmortem staining for localization of SPIO particles was not performed. Rodent studies have shown that SPIO-labeled cells can be visualized with MRI and identified in histological tissue samples up to a year after transplantation [66]. Caution should be exercised when using this approach to track cells long term, however, as the contrast produced by the SPIO particles is dependent on a high density of cells and the amount of contrast from the SPIO particles is finite. As the cells divide, the contrast produced is reduced by a factor of two for the individual cell. Additionally, the particles can be visualized after being ingested by phagocytosing cells, leading to a false positive signal on MRI [71]. More investigation, specifically long-term translational work, must be carried out to determine the utility of SPIO particles as a long-term cell label.

The majority of clinical trials transplanting stem cells into the spinal cord do not incorporate a method for 
tracking cells in vivo. This limitation makes it difficult to confirm that the stem cells have been delivered successfully to the target and even more difficult to track their progress over time. Furthermore, without an effective label, postmortem histological identification is difficult when using conventional methods of identifying the different origins of chimeric tissue. Methodologies for labeling stem cells to track them in vivo and identify them postmortem have great potential. Overcoming these technological hurdles to develop a successful label is essential for progressing the field of stem cell transplantation.

\section{Conclusion}

Basic stem cell research and stem cell translational agendas present an exciting and promising future for spinal cord regeneration. Progress and advancements made within the field of spinal cord medicine will have positive ramifications in the larger stem cell field and numerous other disease states outside the central nervous system. Pioneering work - like that of Geron Corp. and Neuralstem Inc. - not only has advanced the stem cell agenda on the scientific front, but also has made great strides toward overcoming the ethical taboo associated with embryonic stem cells, and has aided other researchers in progressing to clinical trials.

Huge strides have already been made in the translation of stem cells to the clinic. Promising results have been obtained in the preclinical setting and in establishing basic safety data in clinical trials - although it is important to remember that the translation of stem cells to the clinic is still in its infancy, and there are still important hurdles to be overcome and caveats that must not be overlooked. Future work needs to focus on optimizing the delivery and in vivo tracking of the fate of stem cells following transplantations. Great care also needs to be taken with the development of each new source of stem cells, to ensure karotype stability and in screening for potential tumor formation and other adverse events.

With these caveats and future advancements taken into account, this is an exciting time for stem cell medicine and spinal cord medicine. We are only beginning to scrape the surface of the huge potential that stem cells tailored to spinal cord application can offer. However, as is often the case in initial trials to test novel technologies, there will probably be clinical failures before we see successes.

This article is part of a thematic series on Clinical applications of stem cells edited by Mahendra Rao. Other articles in the series can be found online at http://stemcellres.com/series/clinical

\section{Abbreviations}

ALS, amyotrophic lateral sclerosis; FDA, US Food and Drug Administration; MRI, magnetic resonance imaging; $\mathrm{MSC}$, mesenchymal stem cell; $\mathrm{SCl}$, spinal cord injury; SPIO, superparamagnetic iron oxide.

\section{Competing interests}

NMB is the inventor of devices to enable safe and accurate injection of the human spinal cord. Neuralstem Inc. has purchased an exclusive license to this technology. NMB received an inventor's share of this fee, and has the rights to royalty payments for distribution of this technology. The other authors declare that they have no competing interests.

Published: 9 July 2012

\section{References}

1. Vazin T, Freed WJ: Human embryonic stem cells: derivation, culture, and differentiation: a review. Restor Neurol Neurosci 2010, 28:589-603.

2. Murry CE, Keller G: Differentiation of embryonic stem cells to clinically relevant populations: lessons from embryonic development. Cell 2008, 132:661-680.

3. Kim SU: Human neural stem cells genetically modified for brain repair in neurological disorders. Neuropathology 2004, 24:159-171.

4. Xu L, Yan J, Chen D, Welsh AM, Hazel T, Johe K, Hatfield G, Koliatsos VE: Human neural stem cell grafts ameliorate motor neuron disease in SOD-1 transgenic rats. Transplantation 2006, 82:865-875.

5. Caplan Al: Adult mesenchymal stem cells for tissue engineering versus regenerative medicine. J Cell Physiol 2007, 213:341-347.

6. Verma A, Verma N: Induced pluripotent stem cells and promises of neuroregenerative medicine. Neurol India 2011, 59:555-557.

7. Garzon-Muvdi T, Quinones-Hinojosa A: Neural stem cell niches and homing: recruitment and integration into functional tissues. ILAR J 2009, 51:3-23.

8. Witkowska-Zimny M, Wrobel E: Perinatal sources of mesenchymal stem cells: Wharton's jelly, amnion and chorion. Cell Mol Biol Lett 2011, 16:493-514.

9. Geron Cell Therapy [http://cell-therapies.geron.com/]

10. Memorial Hermann [www.memorialhermann.org]

11. NIH Clinical Trials Database [http://clinicaltrials.gov]

12. Neuralstem [www.neuralstem.com]

13. Brainstorm Cell Therapeutics [www.brainstorm-cell.com]

14. TCA Cellular Therapy [www.tcacellulartherapy.com]

15. California Stem Cell, Inc. [http://californiastemcell.com]

16. Himes BT, Neuhuber B, Coleman C, Kushner R, Swanger SA, Kopen GC Wagner J, Shumsky JS, Fischer I: Recovery of function following grafting of human bone marrow-derived stromal cells into the injured spinal cord. Neurorehabil Neural Repair 2006, 20:278-296.

17. Suzuki M, McHugh J, Tork C, Shelley B, Klein S, Aebischer P, Svendsen C: GDNF secreting human neural progenitor cells protect dying motor neurons, but not their projection to muscle, in a rat model of familial ALS. PLOS ONE 2007, 2:e689.

18. Research Ethics and Stem Cells [http://stemcells.nih.gov/info/ethics.asp]

19. Mazzini L, Ferrero I, Luparello V, Rustichelli D, Gunetti M, Mareschi K, Testa L, Stecco A, Tarletti R, Miglioretti M, Fava E, Nasuelli N, Cisari C, Massara M, Vercelli R, Oggioni GD, Carriero A, Cantello R, Monaco F, Fagioli F: Mesenchymal stem cell transplantation in amyotrophic lateral sclerosis: a phase I clinical trial. Exp Neurol 2010, 223:229-237.

20. Mazzini L, Mareschi K, Ferrero I, Miglioretti M, Stecco A, Servo S, Carriero A, Monaco F, Fagioli F: Mesenchymal stromal cell transplantation in amyotrophic lateral sclerosis: a long-term safety study. Cytotherapy 2011, 14:56-60.

21. Mazzini L, Mareschi K, Ferrero I, Vassallo E, Oliveri G, Nasuelli N, Oggioni GD, Testa L, Fagioli F: Stem cell treatment in amyotrophic lateral sclerosis. J Neurol Sci 2008, 265:78-83.

22. Stem Cells Inc. [www.stemcellsinc.com]

23. Imitola J, Raddassi K, Park KI, Mueller FJ, Nieto M, Teng YD, Frenkel D, Li J, Sidman RL, Walsh CA, Snyder EY, Khoury SJ: Directed migration of neural stem cells to sites of CNS injury by the stromal cell-derived factor $1 \mathrm{a} / \mathrm{CXC}$ chemokine receptor 4 pathway. Proc Natl Acad Sci U S A 2004, 101:18117-18122.

24. Zurita M, Vaquero J, Bonilla C, Santos M, De Haro J, Oya S, Aguayo C: Functional recovery of chronic paraplegic pigs after autologous transplantation of bone marrow stromal cells. Transplantation 2008, 86:845-853. 
25. Jeffery ND, Smith PM, Lakatos A, Ibanez C, Ito D, Franklin RJ: Clinical canine spinal cord injury provides an opportunity to examine the issues in translating laboratory techniques into practical therapy. Spinal Cord 2006, 44:584-593.

26. Callera F, de Melo CM: Magnetic resonance tracking of magnetically labeled autologous bone marrow $\mathrm{CD}_{3} 4^{+}$cells transplanted into the spinal cord via lumbar puncture technique in patients with chronic spinal cord injury: CD34+ cells' migration into the injured site. Stem Cells Dev 2007, 16:461-466.

27. Karussis D, Karageorgiou C, Vaknin-Dembinsky A, Gowda-Kurkalli B, Gomori JM, Kassis I, Bulte JW, Petrou P, Ben-Hur T, Abramsky O, Slavin S: Safety and immunological effects of mesenchymal stem cell transplantation in patients with multiple sclerosis and amyotrophic lateral sclerosis. Arch Neurol 2010, 67:1187-1194.

28. Paul C, Samdani AF, Betz RR, Fischer I, Neuhuber B: Grafting of human bone marrow stromal cells into spinal cord injury: a comparison of delivery methods. Spine 2009, 34:328-334

29. Franz CK, Federici T, Yang J, Backus C, Oh SS, Teng Q, Carlton E, Bishop KM, Gasmi M, Bartus RT, Feldman EL, Boulis NM: Intraspinal cord delivery of IGF-I mediated by adeno-associated virus 2 is neuroprotective in a rat model of familial ALS. Neurobiol Dis 2009, 33:473-481.

30. Snyder BR, Gray SJ, Quach ET, Huang JW, Leung CH, Samulski RJ, Boulis NM, Federici T: Comparison of adeno-associated viral vector serotypes for spinal cord and motor neuron gene delivery. Hum Gene Ther 2011, 22:1129-1135.

31. Knoller N, Auerbach G, Fulga V, Zelig G, Attias J, Bakimer R, Marder JB, Yoles E, Belkin M, Schwartz M, Hadani M: Clinical experience using incubated autologous macrophages as a treatment for complete spinal cord injury: phase I study results. J Neurosurg Spine 2005, 3:173-181.

32. Huang H, Chen L, Wang H, Xi H, Gou C, Zhang J, Zhang F, Liu Y: Safety of fetal olfactory ensheathing cell transplantation in patients with chronic spinal cord injury. A 38-month follow-up with MRI. Zhongguo Xiu Fu Chong Jian Waike Za Zhi 2006, 20:439-443.

33. Huang H, Chen L, Wang H, Xiu B, Li B, Wang R, Zhang J, Zhang F, Gu Z, Li Y, Song Y, Hao W, Pang S, Sun J: Influence of patients' age on functional recovery after transplantation of olfactory ensheathing cells into injured spinal cord injury. Chin Med J 2003, 116:1488-1491.

34. Chen L, Huang H, Zhang J, Zhang F, Liu Y, Xi H, Wang H, Gu Z, Song Y, Li Y, Tan $\mathrm{K}$ : Short-term outcome of olfactory ensheathing cells transplantation for treatment of amyotrophic lateral sclerosis. Zhongguo Xiu Fu Chong Jian Wai Ke Za Zhi 2007, 21:961-966

35. Mazzini L, Mareschi K, Ferrero I, Vassallo E, Oliveri G, Nasuelli N, Oggioni GD, Testa L, Fagioli F: Stem cell treatment in amyotrophic lateral sclerosis. J Neuro/ Sci 2008, 265:78-83.

36. Féron F, Perry C, Cochrane J, Licina P, Nowitzke A, Urquhart S, Geraghty T, Mackay-Sim A: Autologous olfactory ensheathing cell transplantation in human spinal cord injury. Brain 2005, 128:2951-2960.

37. Riley J, Butler J, Baker KB, McClelland S, 3rd, Teng Q, Yang J, Garrity-Moses M, Federici T, Boulis NM: Targeted spinal cord therapeutics delivery: stabilized platform and microelectrode recording guidance validation. Stereotact Func Neurosurg 2008, 86:67-74.

38. Riley J, Federici T, Park J, Suzuki M, Franz CK, Tork C, McHugh J, Teng Q, Svendsen C, Boulis NM: Cervical spinal cord therapeutics delivery: preclinical safety validation of a stabilized microinjection platform. Neurosurgery 2009, 65:754-761; discussion 761-762.

39. Federici T, Riley J, Park J, Bain M, Boulis N: Preclinical safety validation of a stabilized viral vector direct injection approach to the cervical spinal cord. Clin Trans Sci 2009, 2:165-167.

40. Raore B, Federici T, Taub J, Wu MC, Riley J, Franz CK, Kliem MA, Snyder B, Feldman EL, Johe K, Boulis NM: Cervical multilevel intraspinal stem cell therapy: assessment of surgical risks in Gottingen minipigs. Spine 2011, 36:E164-E171.

41. Riley JP, Raore B, Taub JS, Federici T, Boulis NM: Platform and cannula design improvements for spinal cord therapeutics delivery. Neurosurgery 2011, 69:ons147-ons154; discussion ons155.

42. Boulis NM, Federici T, Glass JD, Lunn JS, Sakowski SA, Feldman EL: Translational stem cell therapy for amyotrophic lateral sclerosis. Nat Rev Neurol 2011, 8:172-176.

43. Lunn JS, Sakowski SA, Federici T, Glass JD, Boulis NM, Feldman EL: Stem cell technology for the study and treatment of motor neuron diseases. Regen Med 2011, 6:201-213.
44. Aboody K, Capela A, Niazi N, Stern JH, Temple S: Translating stem cell studies to the clinic for CNS repair: current state of the art and the need for a Rosetta Stone. Neuron 2011, 70:597-613.

45. Rudge JS, Silver J: Inhibition of neurite outgrowth on astroglial scars in vitro. J Neurosci 1990, 10:3594-3603.

46. Suzuki M, Svendsen CN: Combining growth factor and stem cell therapy for amyotrophic lateral sclerosis. Trends Neurosci 2008, 31:192-198.

47. Lunn JS, Hefferan MP, Marsala M, Feldman EL: Stem cells: comprehensive treatments for amyotrophic lateral sclerosis in conjunction with growth factor delivery. Growth Factors 2009, 27:133-140.

48. Behrstock S, Ebert A, McHugh J, Vosberg S, Moore J, Schneider B, Capowski E, Hei D, Kordower J, Aebischer P, Svendsen CN: Human neural progenitors deliver glial cell line-derived neurotrophic factor to parkinsonian rodents and aged primates. Gene Ther 2006, 13:379-388.

49. Behrstock S, Ebert AD, Klein S, Schmitt M, Moore JM, Svendsen CN: Lesioninduced increase in survival and migration of human neural progenitor cells releasing GDNF. Cell Transplant 2008, 17:753-762.

50. Kitiyanant N, Kitiyanant Y, Svendsen CN, Thangnipon W: BDNF-, IGF-1- and GDNF-secreting human neural progenitor cells rescue amyloid betainduced toxicity in cultured rat septal neurons. Neurochem Res 2011 37:143-152.

51. Gurney ME, Pu H, Chiu AY, Dal Canto MC, Polchow CY, Alexander DD, Caliendo J, Hentati A, Kwon YW, Deng HX, Chen W, Zhai P, Sufit RL, Siddique $\mathrm{T}$ : Motor neuron degeneration in mice that express a human $\mathrm{Cu}, \mathrm{Zn}$ superoxide dismutase mutation. Science 1994, 264:1772-1775.

52. Howland DS, Liu J, She Y, Goad B, Maragakis NJ, Kim B, Erickson J, Kulik J, DeVito L, Psaltis G, DeGennaro LJ, Cleveland DW, Rothstein JD: Focal loss of the glutamate transporter EAAT2 in a transgenic rat model of SOD1 mutant-mediated amyotrophic lateral sclerosis (ALS). Proc Natl Acad Sci U S A 2002, 99:1604-1609.

53. Matsumoto A, Okada Y, Nakamichi M, Nakamura M, Toyama Y, Sobue G, Nagai M, Aoki M, Itoyama Y, Okano H: Disease progression of human SOD1 (G93A) transgenic ALS model rats. J Neurosci Res 2006, 83:119-133.

54. Xu L, Ryugo DK, Pongstaporn T, Johe K, Koliatsos VE: Human neural stem cell grafts in the spinal cord of SOD1 transgenic rats: differentiation and structural integration into the segmental motor circuitry. J Comp Neurol 2009, 514:297-309.

55. Pearn J: Incidence, prevalence, and gene frequency studies of chronic childhood spinal muscular atrophy. J Med Genet 1978, 15:409-413.

56. Frugier T, Tiziano FD, Cifuentes-Diaz C, Miniou P, Roblot N, Dierich A, Le Meur M, Melki J: Nuclear targeting defect of SMN lacking the C-terminus in a mouse model of spinal muscular atrophy. Hum Mol Genet 2000, 9:849-858.

57. Wyatt TJ, Rossi SL, Siegenthaler MM, Frame J, Robles R, Nistor G, Keirstead HS: Human motor neuron progenitor transplantation leads to endogenous neuronal sparing in 3 models of motor neuron loss. Stem Cells Int 2011 2011:207230.

58. Rossi SL, Nistor G, Wyatt T, Yin HZ, Poole AJ, Weiss JH, Gardener MJ, Dijkstra S, Fischer DF, Keirstead HS: Histological and functional benefit following transplantation of motor neuron progenitors to the injured rat spinal cord. PLoS One 2010, 5:e11852.

59. Uccelli A, Moretta L, Pistoia V: Mesenchymal stem cells in health and disease. Nat Rev Immunol 2008, 8:726-736.

60. Vercelli A, Mereuta OM, Garbossa D, Muraca G, Mareschi K, Rustichelli D, Ferrero I, Mazzini L, Madon E, Fagioli F: Human mesenchymal stem cell transplantation extends survival, improves motor performance and decreases neuroinflammation in mouse model of amyotrophic lateral sclerosis. Neurobiol Dis 2008, 31:395-405

61. Ferrero I, Mazzini L, Rustichelli D, Gunetti M, Mareschi K, Testa L, Nasuelli N, Oggioni GD, Fagioli F: Bone marrow mesenchymal stem cells from healthy donors and sporadic amyotrophic lateral sclerosis patients. Cell Transplant 2008, 17:255-266.

62. Martin AJ, Larson PS, Ostrem JL, Keith Sootsman W, Talke P, Weber OM, Levesque N, Myers J, Starr PA: Placement of deep brain stimulator electrodes using real-time high-field interventional magnetic resonance imaging. Magn Reson Med 2005, 54:1107-1114.

63. Martin AJ, Larson PS, Ostrem JL, Starr PA: Interventional magnetic resonance guidance of deep brain stimulator implantation for Parkinson disease. Top Magn Reson Imaging 2009, 19:213-221.

64. Zhang WY, Ebert AD, Narula J, Wu JC: Imaging cardiac stem cell therapy: translations to human clinical studies. J Cardiovasc Trans/ Res 2011, 4:514-522 
65. McColgan P, Sharma P, Bentley P: Stem cell tracking in human trials: a metaregression. Stem Cell Rev 2011, 7:1031-1040.

66. Obenaus A, Dilmac N, Tone B, Tian HR, Hartman R, Digicaylioglu M, Snyder EY, Ashwal S: Long-term magnetic resonance imaging of stem cells in neonatal ischemic injury. Annals Neurol 2011, 69:282-291.

67. Guzman R, Uchida N, Bliss TM, He D, Christopherson KK, Stellwagen D, Capela A, Greve J, Malenka RC, Moseley ME, Palmer TD, Steinberg GK: Long-term monitoring of transplanted human neural stem cells in developmental and pathological contexts with MRI. Proc Natl Acad Sci U S A 2007, 104:10211-10216

68. Gonzalez-Lara LE, Xu X, Hofstetrova K, Pniak A, Chen Y, McFadden CD, Martinez-Santiesteban FM, Rutt BK, Brown A, Foster PJ: The use of cellular magnetic resonance imaging to track the fate of iron-labeled multipotent stromal cells after direct transplantation in a mouse model of spinal cord injury. Mol Imaging Biol 2011, 13:702-711.

69. Zhu J, Zhou L, XingWu F: Tracking neural stem cells in patients with brain trauma. N Engl J Med 2006, 355:2376-2378.
70. de Vries IJ, Lesterhuis WJ, Barentsz JO, Verdijk P, van Krieken JH, Boerman OC, Oyen WJ, Bonenkamp JJ, Boezeman JB, Adema GJ, Bulte JW, Scheenen TW, Punt CJ, Heerschap A, Figdor CG: Magnetic resonance tracking of dendritic cells in melanoma patients for monitoring of cellular therapy. Nat Biotechnol 2005, 23:1407-1413.

71. Li Z, Suzuki Y, Huang M, Cao F, Xie X, Connolly AJ, Yang PC, Wu JC: Comparison of reporter gene and iron particle labeling for tracking fate of human embryonic stem cells and differentiated endothelial cells in living subjects. Stem Cells 2008, 26:864-873.

doi:10.1186/scrt115

Cite this article as: Donnelly EM, et al.: Stem cell therapy for the spinal cord. Stem Cell Research \& Therapy 2012, 3:24. 